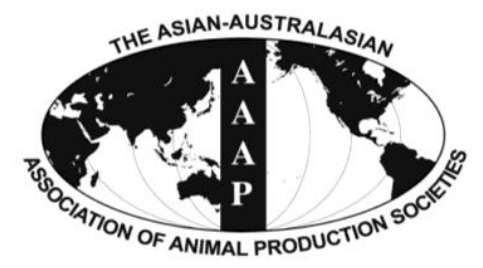

Asian-Aust. J. Anim. Sci.

Vol. 26, No. 3 : 401-407 March 2013

http://dx.doi.org/10.5713/ajas.2012.12444

www.ajas.info

pISSN 1011-2367 elSSN 1976-5517

\title{
Determining of the Effect of Lysine:calorie Ratio on Growth Performance and Blood Urea Nitrogen of Growing Barrows and Gilts in Hot Season and Cool Season in a Commercial Environment
}

\author{
Z. F. Zhang and I. H. Kim* \\ Department of Animal Resource and Science, Dankook University, \\ No.29 Anseodong, Cheonan, Choongnam, 330-714, Korea
}

\begin{abstract}
Two experiments were conducted to determine an optimum Lys:calorie ratio (g of total dietary Lys/Mcal of DE) for growing barrows and gilts in cool and hot seasons in a commercial environment. In Exp. 1, 96 barrows and 96 gilts were randomly allocated in 1 of 4 dietary treatments (2.7, 3.0, 3.3, 3.6 g of Lys/Mcal of DE). Each treatment had 12 replicate pens with 4 pigs per pen. The experiment lasted for $34 \mathrm{~d}$ in the cool season (March 12th to April 15th). Diets were based on corn-wheat-soybean meal. Lys:calorie ratio were attained by adjusting the amount of corn and soybean and supplementation of crystalline Lys. Total Lys intake and available Lys intake were increased $(\mathrm{p}<.05)$ as dietary Lys:calorie ratio increased. The BUN concentration on d 34 for barrows, and BUN change for barrows and gilts linearly increased $(\mathrm{p}<0.05)$ in response to increasing dietary Lys:calorie ratio. For gilts, back fat was decreased and then increased (Quadratically, $\mathrm{p}<0.05$ ) as increasing dietary lys:calorie ratio. Exp. 2 had a similar design as Exp. 1 with the exception that Exp. 2 was conducted in hot season (June 30th to September 11th) for 42 d. Diet of Exp. 2 was the same as Exp. 1. Total Lys intake and available Lys intake increased $(\mathrm{p}<0.05)$ as dietary Lys:calorie increased. On $d 42$, the BUN concentration increased ( $<<0.05)$ in response to the increasing dietary Lys:calorie ratio. In conclusion, dietary Lys:calorie ratio of $2.7 \mathrm{~g}$ of Lys/Mcal of DE could satisfy the requirement of 25 to $50 \mathrm{~kg}$ growing pigs. Increasing dietary Lys:calorie ratio could increase BUN concentration in growing pigs. (Key Words: Blood Urea Nitrogen, Growing Pigs, Growth Performance, Lysine:calorie Ratio)
\end{abstract}

\section{INTRODUCTION}

Feed intake by growing pigs is generally determined by the energy density of the diet (NRC, 1998). Voluntary feed intake of growing pigs given ad libitum access to feed is affected by the dietary energy (DE) content of the diet. Thus, it seems that the amino acid (AA) levels of a diet should be related to its DE concentration (Chiba et al., 1991a;b). Therefore, it is appropriate to change the proportion of dietary AA if DE density or feed intake is altered. The requirement for the AA lysine (Lys) by growing-finishing pigs is commonly expressed as the Lys:calorie ratio.

The increased costs of energy and AA sources for diet formulation has made understanding of the Lys requirements as an essential component of cost-effective growing-finishing feeding strategies, which has led to the need to optimize the Lys:calorie ratio to maximize growth

\footnotetext{
* Corresponding Author: I. H. Kim. Tel: +82-41-550-3652, Fax: +82-41-565-2949, E-mail: inhokim@ dankook.ac.kr Submitted Aug. 17, 2012; Accepted Oct. 31, 2012; Revised Dec. 11, 2012
}

in young and rapidly growing pigs (Schneider et al., 2010). Although growing-finishing Lys requirements have been well studied, modeled, and reported (NRC, 1998), it is generally understood that an optimum Lys:calorie regimen can be largely affected by genetic line, sex, environment, health status, method of interpreting response criteria and economic indicator of success (De La Llata et al., 2001; Main et al., 2008).

Numerous studies have shown that ambient temperature directly affects voluntary feed intake and, therefore, performance of pigs (Verstegen et al., 1978; Close, 1989). Most of these studies dealt with the assessment of additional feed requirement in the cold. Conversely, less information was available on the influence of warm conditions on growth performance. The present study was grounded in the hypothesis that the nature of the season (hot or cool) will influence the Lys requirement of growing pigs in the commercial condition, which has not been investigated. Therefore, the objective of the study was to determine the effect of Lys:calorie ratio on growth 
performance and blood urea nitrogen (BUN) of growing barrows and gilts in hot and cool seasons in a commercial environment.

\section{MATERIALS AND METHODS}

The animal care and use protocol was approved by the Animal Care and Use Committee of Dankook University.

\section{Exp. 1}

Exp. 1 was operated in the cool season during March 12th to April 15th. The average temperature in the barn was $24 \pm 1^{\circ} \mathrm{C}$. A total of 192 crossbreed pigs ((Landrace $\times$ Yorkshire $) \times$ Duroc, 96 barrows and 96 gilts, initial $\mathrm{BW}$ of barrow $=25.2 \pm 0.61 \mathrm{~kg}$, initial $\mathrm{BW}$ of gilts $=$ $26.1 \pm 0.76 \mathrm{~kg}$, age $=63 \mathrm{~d}$ ) were used in a 34-d growth trial to estimate the optimum Lys:calorie ratio. Barrows and Gilts were allotted by BW in a randomized complete block design with four pigs per pen and six replicate pens per treatment. Pigs were fed with increasing Lys:calorie ratio but iso-digestable energy (DE) diets $(2.7,3.0,3.3,3.6 \mathrm{~g}$ of Lys/Mcal of DE using calculated values). Individual pig BW and feed intake by pen were determined on $\mathrm{d} 1$ and $\mathrm{d}$ 34 , and then used to calculate average daily gain (ADG), average daily feed intake (ADFI) and feed:gain ratio (F:G). On d 1 and d 34, blood samples of two pigs from each pen were collected into a nonheparinized tube (Becton Dickinson Vacutainer Systems, Franklin Lakes, USA) to enable evaluation of blood urea nitrogen (BUN). The serum samples were then centrifuged $(2,000 \times \mathrm{g})$ for $30 \mathrm{~min}$ at $4^{\circ} \mathrm{C}$, after which BUN levels was determined using an automatic biochemistry analyzer (HITACHI 747, Periphe Ral Visions Inc, USA). On d 34, backfat thickness of all pigs was measured at the 10th rib $3-\mathrm{cm}$ off the middle of the vertebral line and then lean percentage was calculated by PIGLOG-105 (SKF-Technology, Soborg, Denmark).

\section{Exp. 2}

Exp. 2 was operated in hot season (June 30th to September 11th). The average temperature in the barn was $30 \pm 2{ }^{\circ} \mathrm{C}$. A total of 192 crossbreed pigs ((Landrace $\times$ Yorkshire) $\times$ Duroc, 96 barrows and 96 gilts, initial BW of barrow $=24.1 \pm 0.70 \mathrm{~kg}$, initial BW of gilts $=23.6 \pm 0.93 \mathrm{~kg}$, age $=63 \mathrm{~d}$ ) were used in the $42-\mathrm{d}$ study. The experimental treatments and design were same as Exp. 1. Individual pig $\mathrm{BW}$ and feed intake by pen were determined on $\mathrm{d} 1$ and $\mathrm{d}$ 42 and then used to calculate ADG, ADFI and F:G. On d 1 and $\mathrm{d} 42$, blood was collected and BUN was determined as described in Exp. 1. Also, the backfat thickness and lean percentage was determined by PIGLOG-105 (SKFTechnology, Soborg, Denmark).

\section{Animals housing and diets}

All pigs were housed in identical, double curtain-sided, deep pit research barns constructed like a commercial facilities, with $2 \times 2-\mathrm{m}$ pens and totally slatted concrete floors. The barns were ventilated naturally during warm weather and mechanically during cold weather and lighting was automatically regulated to provide $12-\mathrm{h}$ of artificial light per day. Pigs were allotted randomly to pens and each

Table 1. Compositions of experimental diets (as-fed basis)

\begin{tabular}{|c|c|c|c|c|}
\hline \multirow{2}{*}{ Item } & \multicolumn{4}{|c|}{ Lys:DE ratio (g Lys/Mcal DE) } \\
\hline & 2.7 & 3.0 & 3.3 & 3.6 \\
\hline \multicolumn{5}{|l|}{ Ingredients } \\
\hline Corn & 41.71 & 38.39 & 35.99 & 32.48 \\
\hline Wheat & 25.00 & 25.00 & 25.00 & 25.00 \\
\hline Soybean meal, $48 \% \mathrm{CP}$ & 19.14 & 22.41 & 24.50 & 27.89 \\
\hline Canola meal & 3.00 & 3.00 & 3.00 & 3.00 \\
\hline Animal fat & 3.00 & 3.00 & 3.11 & 3.20 \\
\hline Molasses & 4.00 & 4.00 & 4.00 & 4.00 \\
\hline Sucrose & 0.50 & 0.50 & 0.50 & 0.50 \\
\hline Limestone & 0.38 & 0.41 & 0.39 & 0.37 \\
\hline Dicalcium phosphate & 1.89 & 1.80 & 1.78 & 1.76 \\
\hline Salt & 0.35 & 0.35 & 0.35 & 0.35 \\
\hline L-lysine-HCl & 0.62 & 0.71 & 0.91 & 0.96 \\
\hline DL-methionine & 0.01 & 0.03 & 0.05 & 0.07 \\
\hline L-threonine & & & 0.02 & 0.02 \\
\hline Vitamin premix $^{\mathrm{a}}$ & 0.15 & 0.15 & 0.15 & 0.15 \\
\hline Trace mineral premix ${ }^{b}$ & 0.15 & 0.15 & 0.15 & 0.15 \\
\hline Tylosin (100 g) & 0.10 & 0.10 & 0.10 & 0.10 \\
\hline \multicolumn{5}{|l|}{ Chemical composition } \\
\hline GE (kcal/kg) & 4,075 & 4,065 & 4,070 & 4,055 \\
\hline $\mathrm{CP}(\%)$ & 16.00 & 16.82 & 17.88 & 19.02 \\
\hline Lys $(\%)$ & 0.91 & 1.00 & 1.12 & 1.23 \\
\hline $\operatorname{Thr}(\%)$ & 0.59 & 0.62 & 0.67 & 0.70 \\
\hline Met+cys (\%) & 0.92 & 0.90 & 0.91 & 0.91 \\
\hline $\mathrm{Ca}(\%)$ & 0.69 & 0.70 & 0.68 & 0.71 \\
\hline Available P (\%) & 0.60 & 0.62 & 0.60 & 0.61 \\
\hline \multicolumn{5}{|l|}{ Calculated composition } \\
\hline $\mathrm{DE}^{\mathrm{c}}(\mathrm{kcal} / \mathrm{kg})$ & 3,500 & 3,500 & 3,505 & 3,505 \\
\hline $\mathrm{CP}(\%)$ & 16.25 & 17.03 & 18.12 & 19.43 \\
\hline Lys $(\%)$ & 0.94 & 1.05 & 1.16 & 1.26 \\
\hline $\operatorname{Thr}(\%)$ & 0.61 & 0.65 & 0.68 & 0.72 \\
\hline Met+cys (\%) & 0.89 & 0.89 & 0.89 & 0.89 \\
\hline $\mathrm{Ca}(\%)$ & 0.76 & 0.76 & 0.76 & 0.76 \\
\hline Available P (\%) & 0.59 & 0.59 & 0.60 & 0.60 \\
\hline
\end{tabular}

${ }^{a}$ Provided per kilogram of complete diet: retinyl acetate, 4,000 IU; cholecalciferol, $880 \mathrm{IU}$; dl- $\alpha$-tocopheryl acetate, $50 \mathrm{IU}$; menadione sodium bisulfate complex, $4.2 \mathrm{mg}$; d-calcium pantothenate, $24.6 \mathrm{mg}$; riboflavin, $8.6 \mathrm{mg}$; and vitamin $\mathrm{B}_{12}, 44 \mu \mathrm{g}$.

${ }^{b}$ Provided per kilogram of complete diet: $\mathrm{Cu}$ (as copper sulfate pentahydrate), $15 \mathrm{mg}$, Fe (as ferrous sulfate heptahydrate), $80 \mathrm{mg}$; $\mathrm{Zn}$ (as zinc oxide), $56 \mathrm{mg}$; Mn (as manganese oxide), $73 \mathrm{mg}$; I (as kalium iodate), $0.3 \mathrm{mg}$; Co (as cobalt sulfate pentahydrat), $0.5 \mathrm{mg}$; and Se (as sodium selenate), $0.4 \mathrm{mg}$.

c Computed using NRC (1998) coefficient for digestibility for all ingredients. 
Table 2. Effects of Lys:DE ratios on growth performance and BUN in barrows (Exp. 1)

\begin{tabular}{|c|c|c|c|c|c|c|c|c|}
\hline \multirow{2}{*}{ Item } & \multicolumn{4}{|c|}{ Lys:DE ratio, g Lys/Mcal DE } & \multirow{2}{*}{ SEM $^{\mathrm{a}}$} & \multicolumn{3}{|c|}{ Probability } \\
\hline & 2.7 & 3.0 & 3.3 & 3.6 & & Linear & Quadratic & Cubic \\
\hline \multicolumn{9}{|l|}{$\mathrm{BW}(\mathrm{kg})$} \\
\hline d 1 & 25.5 & 25.2 & 25.0 & 25.0 & & & & \\
\hline d 34 & 49.4 & 49.7 & 49.3 & 49.3 & & & & \\
\hline $\mathrm{ADG}(\mathrm{g})$ & 705 & 719 & 715 & 716 & 26 & 0.82 & 0.81 & 0.84 \\
\hline ADFI (g) & 1,627 & 1,544 & 1,520 & 1,562 & 65 & 0.48 & 0.37 & 0.98 \\
\hline $\mathrm{F}: \mathrm{G}$ & 2.31 & 2.15 & 2.13 & 2.18 & 0.13 & 0.53 & 0.48 & 0.99 \\
\hline Total Lys intake (g) & 15.1 & 16.1 & 17.3 & 19.4 & 0.68 & 0.01 & 0.45 & 0.90 \\
\hline Av. Lys intake (g) & 13.0 & 13.9 & 15.0 & 16.9 & 0.59 & 0.01 & 0.46 & 0.89 \\
\hline Backfat $^{\mathrm{b}}(\mathrm{mm})$ & 8 & 8 & 8 & 8 & 0.34 & 0.46 & 1.00 & 0.08 \\
\hline Lean percentage $(\%)$ & 59.1 & 59.9 & 60.4 & 60.2 & 0.51 & 0.07 & 0.41 & 0.91 \\
\hline \multicolumn{9}{|l|}{ BUN (mg/dl) } \\
\hline d 1 & 10.7 & 12.4 & 12.1 & 10.6 & 1.33 & 0.90 & 0.25 & 0.90 \\
\hline d 34 & 10.5 & 13.1 & 14.7 & 14.2 & 0.84 & 0.01 & 0.08 & 0.75 \\
\hline Change & -0.3 & 0.7 & 2.6 & 3.6 & 1.21 & 0.03 & 0.99 & 0.72 \\
\hline
\end{tabular}

${ }^{\mathrm{a}}$ Standard error mean. ${ }^{\mathrm{b}} 10^{\text {th }}$ rib $3 \mathrm{~cm}$ off the middle of the vertebral line.

pen was provided with a stainless steel self-feeder and a nipple drinker that enabled ad libitum access to feed and water throughout the experiment. Through all the experiment periods, pigs were fed a corn-soybean mealbased diet. The Lys:calorie ratios discussed in this paper are expressed as total grams of Lys/Mcal DE. Increasing Lys:calorie ratio was attained by replacing corn with soybean meal and by adding L-Lys-HCl. All experimental diets were fed in mesh form. Ingredient nutrient levels of all treatment diets were formulated to meet or exceed the recommendation of NRC (1998). The composition of the experiment diet was shown in Table 1.

\section{Sampling and measurement}

Diets were analyzed for $\mathrm{CP}, \mathrm{Ca}, \mathrm{P}$, and individual amino acids by AOAC (1995) procedures. Crude protein was determined by Kjeldahl methodology $(\mathrm{N} \times 6.25)$. Dietary $\mathrm{Ca}$ was assayed by atomic absorption spectrophotometry after wet ash procedures, and $\mathrm{P}$ was determined by colorimetric procedure. Lys and Threonine composition was measured using an amino acid analyzed (Beckman 6300, Beckman Coulter, Inc., Fullerton, CA, USA) after 24-h $6 \mathrm{~N} \mathrm{HCl}$ hydrolysis at $110^{\circ} \mathrm{C}$ (AOAC, 1995). Performic acid was used before hydrolysis to oxidize cysteine and methionine to cysteic acid and methionine sulfone, repectively. Gross energy was determined by measuring the heat of combustion in the samples using a Parr 6100 oxygen bomb calorimeter (Parr instrument Co., Moline, IL, USA).

\section{Statistical analysis}

All data were subjected to ANOVA as a randomized complete block design by using the General Linear Models (GLM) procedure of SAS (SAS Institute, 1996). The pen was considered the experiment unit. Differences among all treatments were separated by Duncan's multiple range test. The linear, quadratic and cubic effects of Lys:calorie ratio among treatments was analyzed using a contrast statement. Results were expressed as the least squares means and SEM. Probability values less than 0.05 were considered significant.

\section{RESULTS AND DISCUSSION}

\section{Exp. 1}

For barrows, the ADG, ADFI, F:G ratio and backfat thickness as measured in 10th-rib back fat were not affected ( $>0.05)$ by dietary treatments through the experimental period (Table 2). However, total Lys intake, available Lys intake was increased (Linear, $\mathrm{p}=0.01, \mathrm{p}=0.01$ ) as the Lys:calorie ratio increased (Linear, $\mathrm{p}=0.01$ ). On $\mathrm{d} 34$, increasing dietary Lys:calorie ratio elevated (Linear, $\mathrm{p}=$ 0.03) BUN level and difference between initial and final BUN levels. Besides, the lean percentage was tend to increase (Linear, $\mathrm{p}=0.07$ ) in response to the increasing dietary Lys:calorie ratio.

For gilts, no difference ( $p>0.05)$ was observed on the ADG and ADFI among all treatments, however, the F:G ratio was tend to be increase (Linear, $p=0.08$ ) by the increasing dietary Lys:calorie ratio (Table 3). Total Lys intake (barrows, 15.1, 16.1, 17.3 and $19.4 \mathrm{~g} / \mathrm{d}$; gilts, 14.7, $17.1,16.9$ and $16.0 \mathrm{~g} / \mathrm{d}$ ) and available Lys intake (barrows, 13.0, 13.9, 15.0 and $16.9 \mathrm{~g} / \mathrm{d}$; gilts, 12.7, 14.8, 14.7 and $16.0 \mathrm{~g} / \mathrm{d}$ ) were improved (Linear, $\mathrm{p}=0.03, \mathrm{p}=0.02$ ) with increasing Lys:calorie ratio. Fat deposition as measured in 10th-rib backfat thickness was decreased and then increased with the increasing Lys:calorie ratio (Quadratic, $\mathrm{p}=0.01$ ) and was minimized at 3.0 and $3.3 \mathrm{~g}$ of Lys/Mcal DE. Lean percentage and final BUN were not affected $(p>0.05)$ by 
Table 3. Effects of Lys:DE ratios on growth performance and BUN in gilts (Exp. 1)

\begin{tabular}{|c|c|c|c|c|c|c|c|c|}
\hline \multirow{2}{*}{ Item } & \multicolumn{4}{|c|}{ Lys:DE ratio, g Lys/Mcal DE } & \multirow{2}{*}{ SEM $^{\mathrm{a}}$} & \multicolumn{3}{|c|}{ Probability } \\
\hline & 2.7 & 3.0 & 3.3 & 3.6 & & Linear & Quadratic & Cubic \\
\hline \multicolumn{9}{|l|}{$\mathrm{BW}(\mathrm{kg})$} \\
\hline d 1 & 26.2 & 26.1 & 26.1 & 26.1 & & & & \\
\hline d 34 & 50.0 & 50.5 & 51.3 & 50.5 & & & & \\
\hline $\mathrm{ADG}(\mathrm{g})$ & 703 & 718 & 742 & 718 & 14 & 0.32 & 0.22 & 0.41 \\
\hline $\mathrm{ADFI}(\mathrm{g})$ & 1,582 & 1,648 & 1,480 & 1,479 & 67 & 0.16 & 0.63 & 0.23 \\
\hline $\mathrm{F}: \mathrm{G}$ & 2.25 & 2.30 & 1.99 & 2.06 & 0.10 & 0.08 & 0.93 & 0.15 \\
\hline Total Lys intake (g) & 14.7 & 17.1 & 16.9 & 18.3 & 0.78 & 0.03 & 0.56 & 0.25 \\
\hline Av. Lys intake (g) & 12.7 & 14.8 & 14.7 & 16.0 & 0.68 & 0.02 & 0.55 & 0.25 \\
\hline $\operatorname{Backfat}^{\mathrm{b}}(\mathrm{mm})$ & 9 & 8 & 8 & 9 & 0.31 & 0.24 & 0.01 & 0.28 \\
\hline Lean percentage $(\%)$ & 59.6 & 60.8 & 60.8 & 60.2 & 0.46 & 0.48 & 0.06 & 0.93 \\
\hline \multicolumn{9}{|l|}{ BUN (mg/dl) } \\
\hline d 1 & 11.3 & 10.6 & 10.5 & 9.1 & 1.31 & 0.28 & 0.80 & 0.74 \\
\hline d 34 & 11.5 & 14.4 & 13.4 & 14.7 & 1.33 & 0.17 & 0.57 & 0.34 \\
\hline Change & 0.2 & 3.8 & 2.9 & 5.6 & 1.03 & 0.01 & 0.68 & 0.11 \\
\hline
\end{tabular}

${ }^{\mathrm{a}}$ Standard error mean. ${ }^{\mathrm{b}} 10$ th rib $3 \mathrm{~cm}$ off the middle of the vertebral line.

dietary treatments on $\mathrm{d} 34$.

\section{Exp. 2}

For barrows, there was no difference $(\mathrm{p}>0.05)$ in ADG, ADFI and $F: G$ ratio among all treatments (Table 4). However, total Lys intake (barrows, 14.0, 17.0, 17.4 and $19.3 \mathrm{~g} / \mathrm{d}$; gilts, $14.3,16.8,17.6$ and $19.6 \mathrm{~g} / \mathrm{d}$ ) and available Lys intake (barrows, 12.1, 14.7, 15.1 and $16.8 \mathrm{~g} / \mathrm{d}$; gilts, $12.3,14.6,15.3$ and $17.1 \mathrm{~g} / \mathrm{d}$ ) were increased (Linear, $\mathrm{p}=$ $0.01, \mathrm{p}=0.01$ ) as the dietary Lys:calorie ratio increased. No difference was observed on fat deposition as measured in 10th-rib back fat and lean percentage. Furthermore, BUN on $\mathrm{d} 42$ was elevated (Linear, $\mathrm{p}=0.04$ ) by the dietary Lys:calorie ratio. NO difference was observed on the difference between initial (d 0) and final (d 42) BUN levels among all treatments.
For gilts, no difference ( $p>0.05)$ was observed on ADG, ADFI, F:G ratio, lean percentage and back fat depth among all treatments (Table 5). However, total Lys intake and available intake were increased (Linear, $\mathrm{p}=0.01, \mathrm{p}=0.01$ ) as the Lys:calorie ratio increased. Final BUN level (d 42) was increased (Linear and quadratic, $\mathrm{p}=0.01$ ) in response to the increasing dietary Lys:calorie ratio. However, the difference between initial and final BUN levels was not affected ( $p>0.05)$ by dietary increasing Lys:calorie level.

\section{DISCUSSION}

The NRC estimated Lys requirement for 20 to $50 \mathrm{~kg}$ pigs is $2.7 \mathrm{~g} / \mathrm{Mcal}$ of DE using corn-soybean meal diet. Presently, the Lys percentage of the diet was $0.93 \%, 1.04 \%$, $1.14 \%$ and $1.24 \%$, respectively. Growth performance was

Table 4. Effects of Lys:DE ratios on growth performance and BUN in barrows (Exp. 2)

\begin{tabular}{|c|c|c|c|c|c|c|c|c|}
\hline \multirow{2}{*}{ Item } & \multicolumn{4}{|c|}{ Lys:DE ratio, g Lys/Mcal DE } & \multirow{2}{*}{$\mathrm{SEM}^{\mathrm{a}}$} & \multicolumn{3}{|c|}{ Probability } \\
\hline & 2.7 & 3.0 & 3.3 & 3.6 & & Linear & Quadratic & Cubic \\
\hline \multicolumn{9}{|l|}{$\overline{\mathrm{BW}}, \mathrm{kg}$} \\
\hline d 1 & 24.1 & 24.0 & 24.0 & 24.1 & & & & \\
\hline $\mathrm{d} 42$ & 51.8 & 52.5 & 52.3 & 52.2 & & & & \\
\hline $\mathrm{ADG}(\mathrm{g})$ & 659 & 679 & 673 & 670 & 16 & 0.72 & 0.49 & 0.72 \\
\hline ADFI (g) & 1,510 & 1,636 & 1,530 & 1,555 & 61 & 0.92 & 0.44 & 0.23 \\
\hline $\mathrm{F}: \mathrm{G}$ & 2.29 & 2.41 & 2.27 & 2.32 & 0.04 & 0.76 & 0.46 & 0.06 \\
\hline Total Lys intake (g) & 14.0 & 17.0 & 17.4 & 19.3 & 0.67 & 0.01 & 0.43 & 0.23 \\
\hline Av. Lys intake (g) & 12.1 & 14.7 & 15.1 & 16.8 & 0.58 & 0.01 & 0.42 & 0.23 \\
\hline Backfat $^{\mathrm{b}}(\mathrm{mm})$ & 10 & 9 & 9 & 9 & 0.31 & 0.25 & 0.27 & 0.29 \\
\hline Lean percentage $(\%)$ & 60.3 & 60.7 & 61.2 & 60.8 & 0.46 & 0.48 & 0.06 & 0.93 \\
\hline \multicolumn{9}{|l|}{ BUN (mg/dl) } \\
\hline d 1 & 11.6 & 10.2 & 12.1 & 11.9 & 1.55 & 0.69 & 0.71 & 0.43 \\
\hline $\mathrm{d} 42$ & 11.3 & 11.1 & 11.6 & 13.8 & 0.80 & 0.04 & 0.15 & 0.77 \\
\hline Change & -0.3 & 1.0 & -0.5 & 1.9 & 1.92 & 0.56 & 0.75 & 0.46 \\
\hline
\end{tabular}

${ }^{a}$ Standard error mean. ${ }^{\mathrm{b}} 10 \mathrm{th}$ rib $3 \mathrm{~cm}$ off the middle of the vertebral line. 
Table 5. Effects of Lys:DE ratios on growth performance and BUN in gilts (Exp. 2)

\begin{tabular}{|c|c|c|c|c|c|c|c|c|}
\hline \multirow{2}{*}{ Item } & \multicolumn{4}{|c|}{ Lys:DE ratio, g Lys/Mcal DE } & \multirow[b]{2}{*}{$\mathrm{SEM}^{\mathrm{a}}$} & \multicolumn{3}{|c|}{ Probability } \\
\hline & 2.7 & 3.0 & 3.3 & 3.6 & & Linear & Quadratic & Cubic \\
\hline \multicolumn{9}{|l|}{$\mathrm{BW}(\mathrm{kg})$} \\
\hline d 1 & 23.80 & 22.60 & 23.80 & 24.30 & & & & \\
\hline $\mathrm{d} 42$ & 51.80 & 50.90 & 53.00 & 52.80 & & & & \\
\hline $\mathrm{ADG}(\mathrm{g})$ & 665 & 672 & 694 & 681 & 26 & 0.62 & 0.74 & 0.51 \\
\hline ADFI (g) & 1,535 & 1,620 & 1,548 & 1,581 & 39 & 0.76 & 0.45 & 0.17 \\
\hline $\mathrm{F}: \mathrm{G}$ & 2.31 & 2.41 & 2.23 & 2.32 & 0.06 & 0.79 & 0.85 & 0.15 \\
\hline Total Lys intake (g) & 14.3 & 16.8 & 17.6 & 19.6 & 0.44 & 0.01 & 0.44 & 0.17 \\
\hline Av. Lys intake (g) & 12.3 & 14.6 & 15.3 & 17.1 & 0.38 & 0.01 & 0.43 & 0.17 \\
\hline Backfat $^{\mathrm{b}}(\mathrm{mm})$ & 10 & 9 & 10 & 9 & 0.31 & 0.27 & 0.33 & 0.36 \\
\hline Lean percentage $(\%)$ & 62.0 & 59.8 & 60.4 & 60.2 & 0.90 & 0.27 & 0.21 & 0.30 \\
\hline \multicolumn{9}{|l|}{ BUN (mg/dl) } \\
\hline d 1 & 10.4 & 12.7 & 12.1 & 11.6 & 2.23 & 0.69 & 0.59 & 0.77 \\
\hline $\mathrm{d} 42$ & 11.7 & 9.6 & 12.4 & 16.2 & 0.86 & 0.01 & 0.01 & 0.48 \\
\hline Change & 1.3 & -3.1 & 0.3 & 4.7 & 2.28 & 0.24 & 0.10 & 0.58 \\
\hline
\end{tabular}

${ }^{\mathrm{a}}$ Standard error mean. ${ }^{\mathrm{b}} 10 \mathrm{th}$ rib $3 \mathrm{~cm}$ off the middle of the vertebral line.

not affected by dietary Lys:Mcal ratio in both barrows and gilts and in both seasons. The highest numerical ADG was obtained for gilts fed a diet contained Lys at $3.3 \mathrm{~g} / \mathrm{Mcal}$ of $\mathrm{DE}$ and barrows fed a diet containing Lys at $3.0 \mathrm{~g} / \mathrm{Mcal}$ of DE. Similar results were observed by Lawrence et al. (1994), who reported that ADG was not affected by sex or dietary treatments $(2.5,3.0,3.5,4.0 \mathrm{~g} \mathrm{Lys} / \mathrm{Mcal}$ of DE). Also, Campbell et al. (1985) and Gatel and Grosjean (1992) reported that ADG was unaffected by dietary treatment in response to increases in the Lys:DE ratio. The failure to observe a response in weight gain due to increased in the Lys:DE ratio may be attributed to the level used in the diet already exceeding the requirement of pigs used in the experiment for maximal $\mathrm{BW}$ gain and another AA that becomes limiting at the Lys:DE ratio, which results in the greatest numerical increase in the BW gain (Lawrence et al., 1994). The present study was carried out at a commercial farm in the summer. Although all ventilation fans were operating, the barn temperature was high. We considered that the high heat stress would influence the feed intake, and so would influence the Lys:DE ratio needed to satisfy the Lys requirement of pigs. The ADG in the cool season (March 12th to April 15th) was numerically higher than that in hot season (June 30th to September 11th). Growth performance can vary markedly depending on the season (Lee et al., 1995; Hsia and Lu, 2004). However, presently, the ADFI of pigs in the cool and hot seasons did not differ, which does not agree with the findings of Rinaldo et al. (2000) who indicated that the decline in FI calculated on an average ambient temperature basis was assessed at $25 \mathrm{~g} / \mathrm{d}$ per $1^{\circ} \mathrm{C}$ increase in temperature between $20^{\circ} \mathrm{C}$ and $27.3^{\circ} \mathrm{C}$ for 15 to $35 \mathrm{~kg}$ growing pigs. The inconsistency may reflect the different experiment periods, which influenced the calculation of ADFI. From the data of Exp. 2 conducted in the hot season, we considered that an increasing Lys:calorie ratio might alleviate the stress of high ambient temperature on ADG. Since the ADFI of pigs did not differ, total Lys intake and available Lys intake were increased as dietary Lys increased.

On the final day of the experiment, the BUN levels were increased as the Lys:DE ratio increased. Generally, there are two dietary factors that can affect BUN. Münchow and Bergner (1968) found a very high negative correlation between the biological value of the feed and BUN. The correlation coefficient was 0.96 for pigs, with egg protein being used as a reference protein. Whang et al. (2003) found that BUN content increased with the protein content in the diet. In agree with our results, Eggum (1970) found that the BUN content was increased when the protein content in the diet was increased. Although in our study, two experiments were conducted separately and hence cannot be directly compared. We found that the BUN concentration was linearly increased with the increasing Lys:DE ratio in both seasons at the end of the experiments. The results concurred with Becker et al. (1992) and Mader and Kreikemeier (2006), who reported that seasonal effects were not found for plasma urea nitrogen concentrations in finishing pigs and heifers. Habeeb et al. (1992) stated that BUN level was decreased in summer due to the decrease in feed intake. However, in our study, we found that ADFI was not affected by the seasons. So we deduce from our results and previous studies that seasons did not affect BUN content significantly, but further researches should be conducted to confirm this.

No difference in the lean percentage was observed among all treatments. Our results were not inconsistent with previous studies. Cooke et al. (1972a,b) found that carcass lean in gilts increases in response to an increase in dietary 
CP. Lodge et al. (1972a,b) reported that carcass lean of gilts and barrows improved substantially only with the first increase in CP from $14 \%$ to $17 \%$, resulting in a Lys:DE ratio of $2.7 \mathrm{~g}$ of Lys/Mcal of $\mathrm{DE}$. There are two explanations for the inconsistency between studies. First, the energy intake may have featured limited protein retention. Higher dietary DE was formulated in the study of Lawrence et al. (1994) while in our study the DE level was lower. Campbell et al $(1985,1988)$ found that $17.5 \% \mathrm{CP}$, or $3.2 \mathrm{~g}$ of Lys/Mcal of DE would maximize protein deposition in boars regardless of the feeding level. Although intact males display a higher potential for protein deposition, and thus lean growth, than gilts or barrows, the findings of Cooke et al. (1972a,b), Lodge et al. (1972a,b) and Campbell et al. $(1985,1988)$ are all in close agreement concerning the protein level needed to maximize lean or protein deposition, regardless of sex. Considering the scope of improvement of genetic selection that has been achieved in recent years, however, the results of the present study indicate that the $\mathrm{CP}$ level of the present diets should have provided sufficient protein for maximal lean and protein deposition at DE level of $3.45 \mathrm{Mcal} / \mathrm{kg}$ diet. The redundant $\mathrm{CP}$ and amino acid may be degraded, as evident by an increased BUN, and the urea nitrogen might increase as the dietary Lys and CP levels increase. Furthermore, in some circumstances the dietary CP and Lys were wasted or the pigs did not have the potential ability to utilize all the dietary CP and Lys of the $\mathrm{DE}$ at $3.45 \mathrm{Mcal} / \mathrm{kg}$ diet. The 10-rib fatness was not affected by the dietary Lys:DE ratio, which agrees with the data of Lawrence et al. (1994) that the rate of fat deposition was unaffected by the Lys:DE ratio $(2.5,3.0,3.5$ and $4.0 \mathrm{~g}$ Lys/Mcal of DE). A high CP and low DE diet was used in this study, and the degradation of redundant protein or protein synthesis would consume energy, thus the dietary energy was not deposited to fat.

\section{CONCLUSIONS}

Dietary Lys:calorie ratios from 2.7 to $3.6 \mathrm{~g}$ of Lys/Mcal of DE did not differ the growth performance of growing pigs. However, barrows and gilts had a numerically highest ADG at the Lys:calorie ratio of 3.0 and $3.3 \mathrm{~g}$ of Lys/Mcal of DE, respectively, in both hot and cool seasons in South Korea. Besides, increasing Lys:calorie ratios could increase the BUN concentration in both seasons.

\section{REFERENCES}

AOAC. 1995. Official method of the analysis of the association of official analytical chemists, 16th Edn. Washington, DC, USA.

Becker, B. A., C. D. Knight, F. C. Buonomo, G. W. Jesse, H. B. Hedrick and C. A. Baile. 1992. Effect of a hot environment on performance, carcass characteristics, and blood hormones and metabolites of pigs treated with porcine somatotropin. J. Anim.
Sci. 70:2732-2740.

Campbell, R. G., M. R. Taverner and D. M. Curic. 1985. The influence of feeding level on the protein requirement of pigs between 20 and $45 \mathrm{~kg}$ live weight. Anim. Prod. 40:489-496.

Campbell, R. G. 1988. Nutritional constraints to lean tissue accretion in farm animals. Nutr. Res. Rev. 1:233-253.

Chiba, L. I., A. J. Lewis and E. R. Peo, Jr. 1991a. Amino acid and energy interrelationships in pigs weighing 20 to 50 kilograms. I. Rate and efficiency of weight gain. J. Anim. Sci. 69:694-707.

Chiba, L. I., A. J. Lewis and E. R. Peo, Jr. 1991b. Amino acid and energy interrelationships in pigs weighing 20 to 50 kilograms: II. Rate and efficiency of protein and fat deposition. J. Anim. Sci. 69:708-718.

Close, W. H. 1989. The influence of the thermal environment on thentary food intake of pigs. In: The voluntary food intake of pigs (Ed. J. M. Forbes, M. A. Varley and T. L. J. Lawrence), 13, Occ. Publ. Br. Soc. Anim. Prod, Edinburgh, pp. 87-96.

Cooke, R., G. A. Lodge and D. Lewis. 1972a. Influence of energy and protein concentration in the diet on the performance of growing pigs 1 . Response to protein intake on a high-energy diet. Anim. Prod. 14:35-46.

Cooke, R., G. A. Lodge and D. Lewis. 1972b. Influence of energy and protein concentration in the diet on the performance of growing pigs 3. Response to differences in levels of both energy and protein. Anim. Prod. 14:219-228.

De La Llata, M., S. S. Dritz, M. R. Langemeier, M. D. Tokach, R. D. Goodband and J. L. Nelssen. 2001. Economics of increasing Lys:calorie ratio and adding dietary fat for growingfinishing pigs reared in a commercial environment. Swine Health Prod. 9:215-223.

Eggum, B. O. 1970. Blood urea measurement as a technique for assessing protein quality. Br. J. Nutr. 24:983-988.

Gatel, F. and F. Grosjean. 1992. Performance of pigs from two genotypes in relation to the amino acid content of the diet. Livest. Prod. Sci. 30:129-140.

Habeeb, A. A. M., I. P. M. Marai and T. H. Kamal. 1992. Heat stress. In: Farm Animals and the Environment (Ed. C. Phillips and D. Piggins). CABI Publishing, Wallingford, UK. pp. 27-47.

Hsia, L. C. and G. H. Lu. 2004. The effect of high environmental temperature and nutrient density on pig performance, conformation and carcass characteristics under restricted feeding system. Asian-Aust. J. Anim. Sci. 17:250-258.

Lawrence, B. V., O. Adeola and T. R. Cline. 1994. Nitrogen utilization and lean growth performance of 20- to 50-kilogram pigs fed diets balanced for Lys:energy ratio. J. Anim. Sci. 72:2887-2895.

Lee, D. N., H. T. Yen and C. S. Chi. 1995. Factors affecting feed intake in boars. J. Chin. Soc. Anim. Sci. 24:237-246.

Lodge, G. A., M. E. Cundy, R. Cooke and D. Lewis. 1972a. Influence of energy and protein concentration in the diet on the performance of growing pigs 2. Differing nutrient density at a constant energy:protein ratio. Anim. Prod. 14:47-55.

Lodge, G. A., B. Hardy and D. Lewis. 1972b. Influence of energy and protein concentration in the diet on the performance of growing pigs 4 . Effects of sex on response to dietary protein level. Anim. Prod. 14:229-239

Mader, T. L. and W. M. Kreikemeier. 2006. Effects of growthpromoting agents and season on blood metabolites and body temperature in heifers. J. Anim. Sci. 84:1030-1037. 
Main, R. G., S. S. Dritz, M. D. Tokach, R. D. Goodband and J. L. Nelssen. 2008. Determining an optimum Lys:calorie ratio for barrows and gilts in a commercial finishing facility. J. Anim. Sci. 86:2190-2207.

Münchow, H. and H. Bergner. 1967. Examination of techniques for protein evaluation of feedstuffs. Archiv. Fur Tierenahrung, 17:141-150.

NRC. 1998. Nutrient Requirements of Swine. 10th rev. ed. Natl. Acad. Press, Washington, DC, USA.

Schneider, J. D., M. D. Tokach, S. S. Dritz, J. L. Nelssen, J. M. DeRouchey and R. D. Goodband. 2010. Determining the effect of Lys:calorie ratio on growth performance of ten- to twentykilogram of body weight nursery pigs of two different genotypes. J. Anim. Sci. 88:137-146.
Rinaldo, D., J. L. dividich and J. Noblet. 2000. Adverse effects of tropical climate on voluntary feed intake and performance of growing pigs. Livest. Prod. Sci. 66:223-234.

SAS Institute, 1996. SAS User's Guide: Statistics. Version 7.0. SAS Institute, Cary, NC, USA.

Verstegen, M. W. A., E. W. Brascamp and W. Van Der Hel. 1978. Growing and fattening of pigs in relation to temperature of housing and feeding level. Can. J. Anim. Sci. 58:1-13.

Whang, K. Y., S. W. Kim, S. M. Donovan, F. K. McKeith and R. A. Easter. 2003. Effects of protein deprivation on subsequent growth performance, gain of body components, and protein requirements in growing pigs. J. Anim. Sci. 81:705-716. 